\title{
PELATIHAN DARING MICROSOFT: EXCEL DAN POWERPOINT PADA SISWA/I SMAN 10 TANGERANG SELATAN
}

\section{MICROSOFT EXCEL AND POWERPOINT ONLINE LEARNING FOR STUDENTS SMAN 10 SOUTH OF TANGERANG}

\author{
Veritia $^{\text {() }}$,Rahmi Hermawati ${ }^{2)}$, Rima Handayani ${ }^{3)}$, Eni Puji Astuti ${ }^{4)}$, Amthy Suraya ${ }^{5)}$ \\ ${ }^{1}$ Manajemen, Fakultas Ekonomi, Universitas Pamulang \\ ${ }^{1}$ Email: dosen00822@unpam.ac.id
}

\begin{abstract}
Abstrak: Pemanfaatan program komputer seperti Microsoft Excel dan PowerPoint masih kurang maksimal di SMAN 10 Tangerang Selatan. Padahal ketrampilan tersebut sangat dibutuhkan di dunia pekerjaan. Tujuan kegiatan pelatihan daring ini diharapkan siswa/i dapat memiliki bekal ketrampilan lebih baik terkait aplikasi komputer dalam sebagai sarana TIK secara praktik. Juga dapat meningkatnya minat dan hasil belajar dengan menggunakan Microsoft Excel dan PowerPoint di kemudian hari. Metode yang akan dilaksanakan dalam kegiatan ini adalah metode ceramah/presentasi untuk memberikan pengetahuan terkait Microsoft Excel dan PowerPoint, metode tanya jawab untuk menggali Microsoft Excel dan PowerPoint dan simulasi secara langsung melalui daring via aplikasi Zoom, dikarenakan adanya pandemik Covid-19. Peserta diikuti 43 siswa/i dan didampingi 7 wali kelas dan kepala sekolah SMAN 10. Hasil dari kegiatan ini didapat hanya 30\% dari peserta pelatihan yang mengumpulkan tugas yang diberikan kepada panitia pelaksana, sisanya $70 \%$ tidak mengumpulkan dikarenakan tidak semua menggunakan laptop. Selama pelaksanaan pelatihan peserta sangat antusias mengikuti pelatihan tersebut. Mereka aktif bertanya jika mengalami kesulitan dalam pembuatan tabel-tabel dan rumus sederhana. Dari hasil latihan yang dikirim oleh siswa-siswa SMAN 10 Tangerang Selatan bagus-bagus, hal ini menunjukkan mereka sangat tertarik dan bersemangat mengikuti pelatihan.
\end{abstract}

Kata Kunci: Pelatihan, Microsoft Excel, PowerPoint, SMAN 10 TangSel

\begin{abstract}
The use of computer programs such as Microsoft Excel and PowerPoint is still not optimal at SMAN 10 Tangerang Selatan. Though these skills are needed in the world of work. The purpose of this online training activity is expected that students will be able to have better skills related to computer applications in practical ICT tools. It can also increase interest and learning outcomes by using Microsoft Excel and PowerPoint later on. The method to be carried out in this activity is the lecture / presentation method to provide knowledge related to Microsoft Excel and PowerPoint, question and answer method to explore Microsoft Excel and PowerPoint and simulations online via the Zoom application, due to the Covid-19 pandemic. Participants were followed by 43 students / I and accompanied by 7 homeroom teachers and principals of SMAN 10. The results of this activity were obtained only $30 \%$ of the trainees collected the assignments given to the implementing committee, the remaining $70 \%$ did not collect because not all used laptops. During the training the participants were very enthusiastic about participating in the training. They actively ask if they have difficulty in making simple tables and formulas. From the results of the training sent by the students of SMAN 10 Tangerang Selatan, this shows that they are very interested and eager to participate in the training.
\end{abstract}

Keywords: Training, Microsoft Excel, PowerPoint, SMAN 10 TangSel 
INTEGRITAS : Jurnal Pengabdian

Vol 4, No 2, Desember 2020

ISSN 2580 - 7978 (cetak) ISSN 2615 - 0794 (online)

\section{PENDAHULUAN}

Belajar dapat dilakukan di mana saja, kapan saja, pendekatan apa saja, bahkan dengan cara apa saja. Di tengah mewabahnya Covid-19 seluruh aktivitas umumnya dilakukan di rumah melalui sistem dalam jaringan (daring). Kegiatan pembelajaran, pelatihan mau kegiatan lainnya yang selama ini dilakukan dengan tatap muka (offline) berubah menjadi online. Dengan menggunakan sistem daring, siswa tetap dapat belajar dan mengasah kemampuan akademik maupun non akademik.Menurut Pribadi (2010) dalam Kartikawati (2016), belajar adalah kegiatan yang dilakukan oleh seseorang agar memiliki kompetensi berupa keterampilan dan pengetahuan yang diperlukan. Proses belajar pada dasarnya dilakukan untuk meningkatkan kemampuan atau kompetensi personal.

Perkembangan era globalisasi dan Revolusi Industry 4.0 tersebut, dunia teknologi informasi dan komunikasi juga berkembang dengan pesat dan menjadi kebutuhan primer bagi banyak kalangan. Gunawan (2019) menyatakan di Indonesia, pemerintah Republik Indonesia, berkomitmen untuk meningkatkan posisi daya saing Indonesia dari urutan ke-41 menjadi ke -39 dari 138 negara yang tercatat dalam Global Competitivenes Report 2016-2017. Untuk mencapai itu maka solusinya adalah Indonesia harus terus berinovasi dan melaksanakan revolusi industri 4.0 ini.

Melakukan pembelajaran daring merupakan salah satu manfaat dari teknologi. Dikarenakan ada peraturan pemerintah terkait pembatasan ke luar rumah, maka siswa mau tidak mau harus bisa beradaptasi dengan teknologi. Perubahan adaptasi teknologi ini tidak bisa dihindari termasuk para pelajar, jika tidak tentu akan tertinggal. Penguasaan terhadap perangkat teknologi Informasi perlu diajarkan pada semua tingkatan, termasuk Siswa Sekolah Menengah Atas.

Peran mata pelajaran TIK (Teknologi Informasi dan Komunikasi) di era revolusi industri 4.0 sangat dibutuhkan bagi para siswa sebagai bekal bagi mereka dalam menghadapi perubahan dan tuntutan jaman. Sejak adanya penerapan kurikulum 2013 (K-13), TIK hanya diajarkan pada Sekolah Menengah Kejuruan untuk lintas minat atau pendalaman minat bidang teknologi informasi dan komunikasi saja, tidak diwajibkan secara umum. 
INTEGRITAS : Jurnal Pengabdian

Vol 4, No 2, Desember 2020

ISSN $2580-7978$ (cetak) ISSN 2615 - 0794 (online)

Apalagi di Sekolah Menengah Atas atau Sekolah Menengah Umum pengenalan komputer khususnya Microsoft Office kurang menjadi perhatian karena mereka setelah lulus diharapkan untuk melanjutkan studi ke Perguruan Tinggi. Mereka tidak dididik dan dilatih untuk menjadi seorang professional atau tenaga terlatih untuk bekerja setelah menuntaskan belajarnya.

Beberapa kegiatan PKM yang sama telah dilakukan misalnya saja, Wibowo (2018) melakukan pelatihan Microsoft Excel dan PowerPoint pada Perangkat Desa Kecamatan Jumantono, Kabupaten Karanganyar. Lalu Mutiarni (2016), melakukan penerapan pembelajaran Micrososft Excel berbasis interaktif pada mata kuliah teknologi informasi dan komunikasi (TIK) di STIE PGRI Dewantara Jombang. Hasilnya adalah sangat efektif dengan skor rerata sebesar $80 \%$. Lalu ada Sormin, dkk (2018) yang melakukan PKM terkait pemanfaatan perangkat lunak dalam membantu Kinerja Kepala Desa SeKecamatan Batang Angkola. Sedangkan Elpira \& Ghufron (2015), meneliti pengaruh penggunaan media Powerpoint terhadap minat dan hasil belajar IPA siswa kelas IV SD Muhammadiyah Sagan. Hasilnya adalah Terdapat pengaruh media Powerpoint terhadap hasil belajar IPA siswa kelompok eksperimen pada pembelajaran yang menggunakan media Powerpoint. Hasil belajar IPA siswa kelas IV SD Muhammadiyah Sagan meningkat 14,01 atau $14,01 \%$, yaitu dari hasil selisih rerataan pretest 71,82 dengan hasil rerataan post-test 85,83 .

Di SMAN 10 Tangerang Selatan sendiri masih belum memaksimalkan pembelajaran Teknologi Informasi dan Komunikasi ini. Misalnya saja, pemanfaatan sarana lab komputer yang belum dilaksanakan secara maksimal digunakan siswa karena tidak adanya mata pelajaran yang berkaitan secara langsung dengan komputer sehingga pemanfaatan program komputer seperti Microsoft Excel danPowerPoint kurang maksimal. Padahal kemampuan menguasai program komputer Microsoft ini merupakan ketrampilan yang umum di minta pada dunia kerja.

Berdasarkan permasalahan diatas kami berinisiatif untuk membentuk tim Pengabdian Kepada Masyarakat untuk memberikan pelatihan Microsoft Excel dan PowerPoint secara daring bagi siswa dan siswi SMAN 10 TANGERANG 
INTEGRITAS : Jurnal Pengabdian

Vol 4, No 2, Desember 2020

ISSN 2580 - 7978 (cetak) ISSN 2615 - 0794 (online)

SELATAN, Jl. Tegal Rotan Raya Sektor 9, Bintaro, Sawah Baru, Ciputat Tangerang Selatan, Banten.

Tujuan kegiatan pelatihan terkait Microsoft Excel dan PowerPoint (PPT) yang akan dilaksanakan di SMAN 10 Tangerang Selatan ini diharapkan siswa/i dapat memiliki bekal ketrampilan penggunaan aplikasi komputer lebih dalam sebagai sarana TIK secara praktik. Juga dapat meningkatnya minat dan hasil belajar dengan menggunakan Microsoft Excel dan PowerPoint di kemudian hari.

\section{METODE}

Berdasarkan informasi yang diperoleh terkait permasalahan mitra seperti yang diuraikan sebelumnya, tim Pengabdian Kepada Masyarakat ingin membantu memberikan solusi terhadap permasalahan yang dihadapi mitra. Permasalahan yang dihadapi siswa-siswi SMAN 10 Tangerang Selatan adalah banyaknya mitra yang belum terbiasa dengan tool-tool yang banyak disediakan pada perangkat lunak Microsoft seperti Excel dan PowerPoint. Beberapa kendala yang sering dijumpai adalah kurang maksimalnya penggunaan fungsi rumus-rumus kondisi pada Excel dan animasi serta multimedia di PowerPoint.

Tim pengabdian Kepada Masyarakat (PKM) ini mencoba menawarkan solusi dengan memberikan pelatihan dan praktek secara berkala. Solusi yang ditawarkan adalah pelatihan peningkatan ketrampilan penggunaan perangkat aplikasi Microsoft (Excel dan PowerPoint) pada siswa dan siswi SMAN 10 Tangerang Selatan. Fokus pelatihan PKM ini adalah penggunaan fungsi rumusrumus kondisi pada Excel dan animasi serta multimedia di PowerPoint untuk kegiatan belajar mengajar. MicrosoftWords tidak diberikan karena pada umumnya siswa dan siswi SMAN 10 Tangerang Selatan sudah memahami dan menguasai aplikasi ini dibanding Excel dan PowerPoint.

Perangkat lunak seperti Excel dan PowerPoint atau Office sendiri adalah perangkat lunak yang sudah banyak dipakai di berbagai instansi. Selain itu perangkat lunak Office memiliki kebutuhan spesifikasi komputer yang tidak tinggi, karena dapat berjalan pada komputer dengan spesifikasi rendah. Hal ini tidak memberatkan dan menjadi kendala bagi mitra kelak setelah kegiatan pelatihan berakhir mereka dapat berlatih dengan computer pribadi. 
INTEGRITAS : Jurnal Pengabdian

Vol 4, No 2, Desember 2020

ISSN 2580 - 7978 (cetak) ISSN 2615 - 0794 (online)

Target khalayak peserta dari kegiatan ini adalah sekitar 49 siswa dan siswi yang semuanya merupakan pelajar di SMAN 10, Tangerang Selatan. Adapun syarat untuk menjadi peserta, seperti yang telah disepakati dengan pihak sekolah sebagai mitra adalah :

1. Peserta ditunjuk oleh wali kelas dengan pengetahuan dan persetujuan Kepala Sekolah SMAN 10 Tangerang Selatan, yakni kelas X.

2. Peserta bersedia mengikuti kegiatan selama 2 (dua) hari, dari awal acara PKM daring ini dilakukan hingga selesai. Sebagai bukti, para siswa dan siswi SMAN 10 Tangerang Selatan akan mengisi daftar kehadiran dengan menggunakan Google Form dan juga dilihat dari foto ketika mereka menghadiri kegiatan PKM daring ini via aplikasi Zoom.

3. Siswa dan siswi SMAN 10 Tangerang Selatan akan di kawal oleh beberapa perwakilan sekolah untuk masuk juga ke dalam acara daring ini.

Metode yang akan dilaksanakan dalam kegiatan ini adalah metode ceramah/presentasi, metode tanya jawab dan simulasi secara langsung melalui daring via aplikasi Zoom. Hal ini dilakukan karena adanya pembatasan mobilitas akibat pandemi Covid-19. Berikut adalah penjelasan mengenai metode yang dilakukan dalam kegiatan Pengabdian Kepada Masyarakat (PKM):

\section{Metode Ceramah/Presentasi}

Metode ceramah/presentasi dipilih untuk memberikan penjelasan tentang:

a) Memberikan pengetahuan terkait dengan MicrosoftOffice yaitu Excel yang banyak belum dipahami oleh siswa dan siswsi SMAN 10 Tangerang Selatan.

b) Memberikan pengetahuan terkait PowerPoint agar siswa dan siswi SMAN 10 Tangerang Selatan dapat meningkatkan pemahamannya.

\section{Metode Tanya Jawab}

Metode tanya jawab sangat penting bagi para peserta pelatihan. Metode ini memungkinkan para siswa dan siswi SMAN 10 Tangerang Selatan menggali pengetahuan sebanyak-banyaknya tentang pengoperasian microsoft office Excel dan PowerPoint. 
INTEGRITAS : Jurnal Pengabdian

Vol 4, No 2, Desember 2020

ISSN 2580 - 7978 (cetak) ISSN 2615 - 0794 (online)

\section{Metode Simulasi/Praktek}

Metode simulasi ini diberikan kepada para peserta pelatihan dalam memberikan kesempatan mempraktekan materi yang diperoleh. Harapannya, peserta pelatihan dapat menguasai materi pelatihan yang diterima, mengetahui tingkat kemampuan pengoperasian microsoft office excel dan power point.

Sebelum dimulai kegiatan praktikum diawali dengan pengenalan Microsoft Excel dan Microsoft PowerPoint. Pengenalan digunakan untuk membantu peserta didik dalam mengoperasikan perangkat lunak. Kegiatan pelatihan ini dilakukan di rumah masing-masing siswa/i SMAN 10 Tangerang Selatan.

Masing-masing peserta menggunakan 1 unit laptop yang mereka miliki. Kegiatan dilaksanakan dalam waktu 2 (dua) hari dengan durasi pelatihan adalah 8 (delapan) jam, terdiri dari:

\section{Hari Pertama:}

1. 30 menit pengenalan Excel dan PowerPoint

2. 180 menit untuk pelatihan dengan 2 sesi, yaitu Excel dan PowerPoint

3. 30 menit untuk evaluasi keseluruhan materi.

Adapun pembagian materi pelatihannya adalah sebagai berikut:

1. Sesi 1 untuk materi Excel membuat suatu laporan berbentuk tabel dan angka.

2. Sesi 2 untuk materi PowerPoint membuat materi tentang belajar di rumah saat Pandemi Covid-19.

Setelah siswa dan siswi SMAN 10 Tangerang Selatan mendengarkan presentasi narasumber, mereka melakukan latihan dengan perangkat laptop masing-masing dan mengumpulkan melalui email dua jam setelah pelatihan. Kemudian tim PKM akan memeriksa dan menilai latihan yang mereka kerjakan.

\section{Hari Kedua :}

Diwaktu yang sama, peserta yang telah mengikuti pelatihan di hari pertama diharapkan mengikuti kembali di hari kedua. Di hari kedua ini evaluasi pelatihan akan diberikan. Evaluasi keberhasilan kegiatan pelatihan ini dilakukan setelah masing-masing sesi pelatihan dan pada akhir kegiatan. Setiap sesi pelatihan akan dilakukan evaluasi kemudian dilanjutkan evaluasi materi secara keseluruhan di akhir kegiatan. 


\section{INTEGRITAS : Jurnal Pengabdian}

Vol 4, No 2, Desember 2020

ISSN 2580 - 7978 (cetak) ISSN 2615 - 0794 (online)

Hari kedua ini, peserta akan melakukan tanya jawab dan mendengarkan hasil evaluasi dari latihan Microsoft Office Excel dan PowerPoint yang telah mereka lakukan. 5 (lima) terbaik pengerjaan tugas latihan excel dan 5 (lima) terbaik dari pengerjaan tugas PowerPoint akan diumumkan. Agar siswa dan siswi termotivasi, maka tim PKM akan memberikan hadiah kepada 10 peserta yang terbaik dalam mengikuti dan mengerjakan pelatihan ini.

Adapun indikator keberhasilan kegiatan ini dilihat dari respon kepuasan dari para peserta melalui evaluasi yang diberikan. Evaluasi kegiatan juga dilakukan berupa kuesioner yang diisi peserta, terkait dengan kegiatan yang telah diikuti. Kemampuan pemahaman peserta diperoleh berdasarkan hasil evaluasi yang didapat dari peserta.

Evaluasi sangat penting bagi berjalannya suatu program, baik itu program pendidikan, pembelajaran, atau pun pelatihan. Biasanya tujuan dari diadakannya evaluasi ialah untuk mengetahui apakah program yang sudah dijalankan seperti program-program tersebut di atas, tersampaikan kepada peserta dengan baik, atau sesuai dengan target/tujuan dari program tersebut, ataukah belum sama sekali. Maka tim PKM juga melakukan evaluasi selama kegiatan berlangsung.

\section{HASIL DAN PEMBAHASAN}

Kegiatan pelatihan pengoperasian Microsoft Office ini dilaksanakan selama dua hari yakni 13 dan 14 Mei 2020. Peserta dihadiri oleh 43 siswa-siswa kelas X SMAN 10 Tangerang Selatan dengan didampingi oleh 7 wali kelasnya masingmasing. Serta dihadiri Kepala Sekolah SMAN 10 Tangerang Selatan, yakni bapak Nursalim, S.Pd. Berikut visualisasi pelatihan daring di SMAN 10 Tangerang Selatan dapat dilihat pada gambar 1 dan 2 dibawah ini:

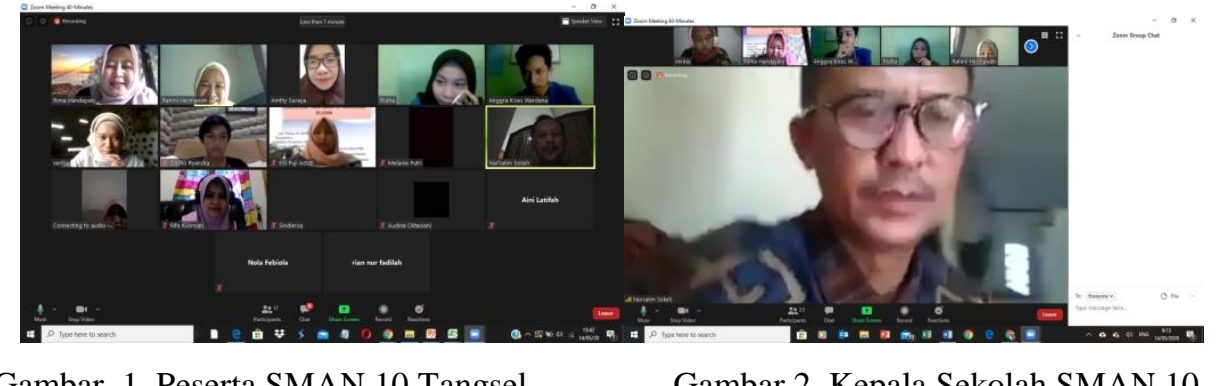




\section{INTEGRITAS : Jurnal Pengabdian}

Vol 4, No 2, Desember 2020

ISSN 2580 - 7978 (cetak) ISSN 2615 - 0794 (online)

Materi pada pelatihan ini terdiri dari dua submateri pokok antara lain Microsoft Excel dan Microsoft PowerPoint. Materi Microsoft Office Excel dimulai tanggal 13 Mei 2020, pada pukul 10.00WIB sampai 12.00 WIB dengan pokok materi pembuatan laporan pengeluaran bulanan. Kemudian pada jam 13.00 WIB sampai 14.00 WIB dilanjutkan materi PowertPoint mengenai pembuatan dasar slide gambar untuk presentasi. Materi disampaikan dengan metode ceramah dan demonstrasi, setelah pemaparan submateri langsung dilanjutkan dengan praktikum. Berikut adalah visualisasi materi dari acara pelatihan ini, dapat dilihat pada gambar 3 dan 4 dibawah ini:
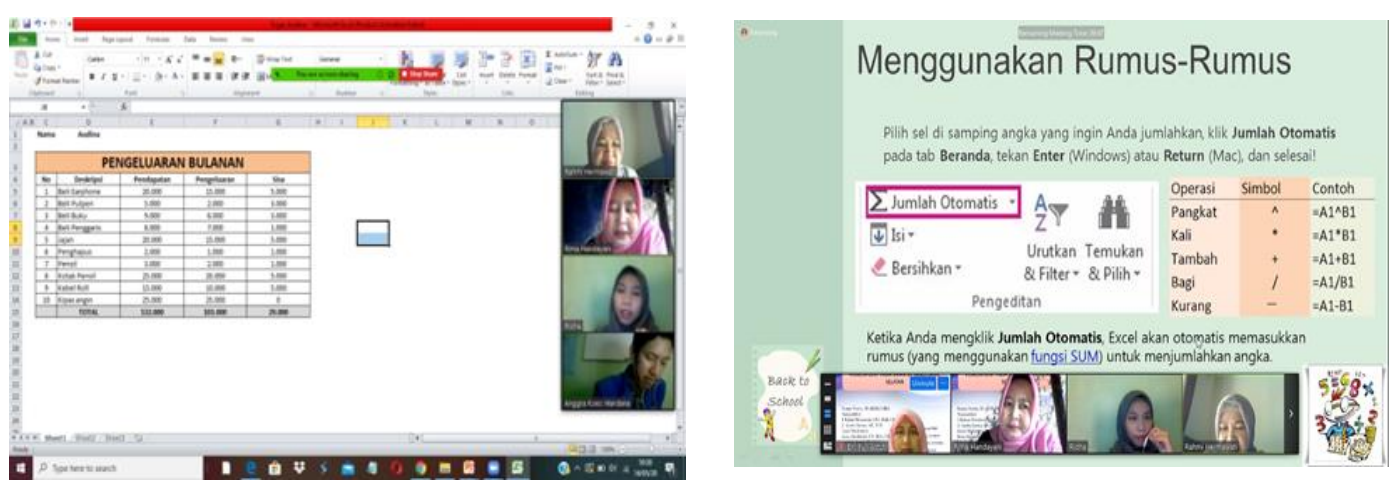

Gambar 3\& 4. Visualisasi materi pelatihan daring Microsoft Excel di SMAN 10 Tangsel, 2020.

Tugas mahasiswa yang diikut sertakan dalam PKM tersebut adalah mencatat siswa-siswi yang hadir dengan melihat jumlah peserta yang masuk ke zoom, mencatat siswa-siswi yang mengumpulkan latihan, menjadi presenter serta membaca doa awal dan penutupan. Materi yang disampaikan berupa tata cara pembuatan table, pengaturan margin, pembuatan format tanggal dan waktu, tata cara pengaturan teks dalam tabel, serta pemahaman penulisan formula logika matematika dengan baik dan benar. Sedangkan pada pelatihan PowerPoint siswa berupa cara menuliskan, di dalam PPT, menambah slide, mencopy slide, menambah gambar dan sebagainya. Kemudian sebagai latihan mereka diminta untuk membuat informasi dengan tema "Kegiatan Belajar Selama COVID-19 Yang dilakukan Oleh Siswa/i SMAN 10 Tangerang Selatan”. Gambar kegiatan pelatihan daring Microsoft PowerPoint dapat dilihat pada gambar $5 \& 6$ dibawah ini: 


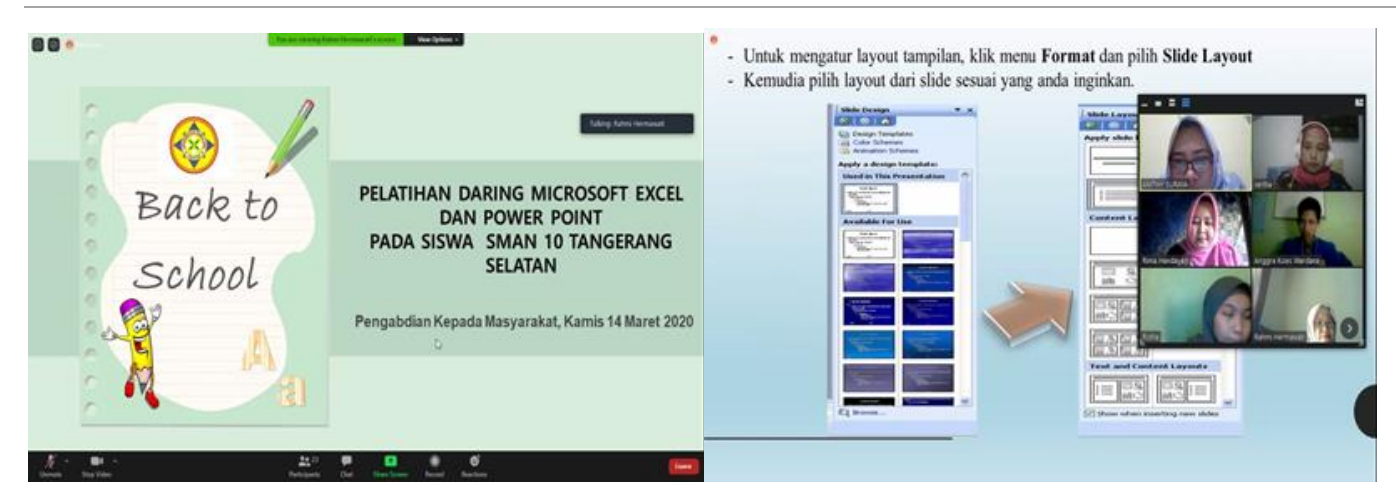

Gambar 5\&6. Visualisasi materi pelatihan daring PowerPoint di SMAN 10 Tangsel, 2020.

Agar siswa/i termotivasi, kami memberikan evaluasi pelatihan ini di hari kedua yakni pada tanggal 14 Mei 2020. Penilaian dilihat dari hasil pekerjaan yang sesuai dengan pemberian materi. Untuk excel, hasil harus sesuai dan menggunakan rumus yang diajarkan dalam sebuah table. Sedangkan untuk pelatihan PPT penilaian hasil evaluasi dilihat dari ide original, menarik dan kreativitas para siswa/i.

Hasil kegiatan PKM daring ini menunjukkan hanya 30\% dari peserta pelatihan yang mengumpulkan tugas yang diberikan kepada panitia pelaksana PKM, sisanya 70\% tidak mengumpulkan dikarenakan tidak semua menggunakan laptop. Belum lagi hampir $50 \%$ peserta mengalami kendala teknis terkait jaringan internet. Jadi selama pelatihan daring dilaksanakan, peserta beberapa kali harus $\log$ in ke acara pelatihan daring ini. Mayoritas mereka menggunakan aplikasi Zoom dari smartphone. Peserta mengikuti pelatihan selama dua hari diawasi wali kelas dan kepala sekolah selama dua hari. Selama pelaksanaan pelatihan peserta sangat antusias mengikuti pelatihan tersebut. Mereka aktif bertanya jika mengalami kesulitan dalam pembuatan tabel-tabel dan rumus sederhana. Dari hasil latihan yang dikirim oleh siswa-siswa SMAN 10 Tangerang Selatan bagusbagus, hal ini menunjukkan mereka sangat tertarik dan bersemangat mengikuti pelatihan. Beberapa pemenang untuk pelatihan ini diberikan pulsa dan sertifikat sebagai hadiah untuk keaktifan dan antusias mereka dalam mengikut pelatihan daring ini. 
INTEGRITAS : Jurnal Pengabdian

Vol 4, No 2, Desember 2020

ISSN 2580 - 7978 (cetak) ISSN 2615 - 0794 (online)

\section{KESIMPULAN}

Pelaksanaan pelatihan daring pengoperasian Microsoft Excel dan PowerPoint pada SMAN 10 Tangerang Selatan berlangsung dengan lancar. Melalui kegiatan sosialisasi dan pelatihan MS. Office Excel dan PowerPoint ini mereka dapat mengetahui peran Teknologi Informasi untuk menambah pengetahuan, wawasan, dan dapat menggunakan salah satu aplikasi TI untuk mengembangkan kemampuan administrasi di dunia kerja.

Setelah mengikuti pelatihan daring ini, peserta menjadi paham bahwa dengan menguasi Microsoft Excel dan PowerPoint sangat membantu di dalam membuat laporan dan presentasi yang bisa dilakukan untuk pelajaran sekolah. Peserta akhirnya mampu menggunakan tools yang ada pada Microsoft Excel dan PowerPoint, khususnya yang mereka gunakan untuk pembuatan laporan uang bulanan seperti penggunaan margin, pengaturan teks dalam table, pembuatan format tanggal dan waktu, penggunaan rumus tambah, bagi, kali, kurang serta penyusunan format logika matematika dengan baik dan benar yang dapat diterapkan pada pelaksanaan tugas masing-masing dan sangat membantu pada pembuatan tugas materi pelajaran presentasi. Dengan antusiasnya peserta, semoga akan meningkatkan minat siswa/i dalam melakukan tugas pekerjaan sekolah nanti.

Semoga pelatihan pengoperasian komputer ini dapat dilanjutkan dengan tatap muka setelah pandemi virus Corona berakhir. Pelatihan lanjutan atau advance diperlukan untuk mempersiapkan siswa jika setelah ingin langsung bekerja.

\section{UCAPAN TERIMA KASIH}

Kami ucapkan terima kasih tak terhingga kepada Kepala Sekolah SMAN 10 Tangerang Selatan, LPPM dan para pimpinan Universitas Pamulang. Tim Pengabdi serta pelajar di SMAN 10 Tangerang selatan yang telah banyak membantu hingga bisa terwujudnya acara ini.

\section{DAFTAR PUSTAKA}

Elpira, N., \& Ghufron, A. (2015). Pengaruh penggunaan media powerpoint terhadap Minat dan hasil belajar ipa siswa kelas IV SD. Jurnal Inovasi Teknologi Pendidikan, 2(1), 94-104. 
INTEGRITAS : Jurnal Pengabdian

Vol 4, No 2, Desember 2020

ISSN $2580-7978$ (cetak) ISSN 2615 - 0794 (online)

Gunawan (2019). Mencari Peluang di REVOLUSI INDUSTRI 4.0 Untuk Melalui Era Disrupsi 4.0. Queency Publisher.

Kartikawati, E. (2016). Memperkenalkan Siswa pada Komputer sebagai Salah Satu Penerapan Strategi Pembelajaran Sambil Bermain.

Mutiarni, R. (2016). Efektivitas Pembelajaran Micrososft Excel Berbasis Interaktif Pada Mata Kuliah Teknologi Informasi Dan Komunikasi (TIK) (Study Kasus Pada Mahasiswa Manajemen STIE PGRI Dewantara Jombang). Eksis: Jurnal Riset Ekonomi dan Bisnis, 11(2).

Sormin, M. A., Sahara, N., \& Agustina, L. (2018). Pelatihan Pemanfaatan Perangkat Lunak (Microsoft Office Word, Excel, Power Point) Dalam Kinerja Pengolahan Data Di Pemerintahan Desa Bagikepala Desa SeKecamatan Batang Angkola. Martabe: Jurnal Pengabdian Kepada Masyarakat, 1(2), 78-82.

Wibowo, E. (2018). Pelatihan Microsoft Excel dan PowerPoint bagi Perangkat Desa sebagai Upaya Peningkatan Administrasi Desa yang Berkualitas di Kecamatan Jumantono Kabupaten Karanganyar. Adi Widya: Jurnal Pengabdian Masyarakat, 1(1). 